\title{
FLEXIBLE DESIGNING OF LARGE SPORTS COMPLEX
}

\author{
M. KOŚMIEJA ${ }^{1}$, J. PASŁAWSKI ${ }^{2}$
}

\begin{abstract}
The article presents the ideas of flexible design in the construction sector. Flexibility in the construction sector was discussed and defined between typical and flexible approaches to design. The idea applied during the economic effectiveness analysis of construction projects was introduced. The issue of flexibility was discussed based on the example of construction of a sports facility - The National Stadium in Warsaw. An effectiveness analysis was applied for variant solutions.
\end{abstract}

Keywords: flexibility, sport complex, design, net present value

\section{INTRODUCTION}

In current times, fast technological advancement is an important factor causing significant difficulties in designing construction objects. It has a particularly strong effect on the large sports facilities used for many years. Very often, the issue of designing projects accounts for the possibility of changes throughout their life cycle becomes important. It is this flexibility of the design that provides the opportunity to adapt to potential changes [1]. Seeing how the large sports facilities are used for a long time period, changes to them are certain and can pertain to the conditions of use as well as the requirements set forth or technological developments [10]. Establishing the moment that the need for changes arises is not difficult, that is why introducing a new approach based on flexibility, which is the possibility of introducing analyses of scenarios calling for changes in the configuration of the parameters of a system or its elements over time, is justified.

\footnotetext{
${ }^{1}$ M.Sc., Eng., Poznań University of Technology, Faculty of Civil and Environmental Engineering, Al. Piotrowo 5, 60-965 Poznań, Poland, e-mail: maria.kosmieja@put.poznan.pl

${ }^{2}$ Prof., PhD., Eng., Poznań University of Technology, Faculty of Civil and Environmental Engineering, Al. Piotrowo 5, 60-965 Poznań, Poland, e-mail: jerzy.paslawski@put.poznan.pl
} 
In order to present the flexible approach to project design in construction, a case study has been carried out and described in the article in addition to the theoretical approach to the problem. The topic regards the construction of the football stadium in Warsaw. Changes concerning the requirements and parameters over time are to be expected for the entire period during which these types of objects are utilized, that is throughout their so called life cycle. As a general rule, a tendency for increasing requirements (e.g. gradually increasing the amount of users for a buffer parking lot, the number of airport passengers, an increase in the number of highway users, etc.) ought to be expected.

\section{DEFINITION OF FLEXIBILITY}

Although flexibility is a frequently encountered phenomenon in everyday life, it is difficult to agree on an accurate definition which would apply to studies in the field of construction management. The great majority of literature on flexibility focuses on flexible production systems [7] or on the strategic management of an organization [14, 4]. What makes this different from flexibility in construction is the focus on the object of influence. In general, the approach focuses on the client's requirements, while in construction, it concentrates on the influence of the environment. In general, it can therefore be stated that flexibility is the ability of the system to respond to external or internal changes without sacrificing values in terms of: quality, time, and cost effectiveness. Following this train of thought, the following definitions of flexibility can be proposed depending on the stages of the investment process [10]:

Phases of realization: the ability of the system to act in such a way that various tactics can be reversed in response to the changing environment, which is based on a proactive approach (the monitoring of ongoing processes and surroundings) and aims to limit dangers and take advantage of opportunities, assuming the maximization of profits (at a constant agreed price, this signifies the minimization of costs)

Phases of exploitation: The ability of the system to switch between various options of flexibility depending on the changing external conditions during the course of exploitation, assuming maximization of NPVs (Net Present Values).

\section{FLEXIBLE APPROACH VS TYPICAL DESIGN}


For over the past 80 years, many researchers have been interested in issues connected with managing building processes. Below are some who have presented solutions applying the idea of flexibility:

- Schumpeter; in 1943 described the idea of flexibility in managing production [11]

- Kapliński in 1978 presented the concept of buffering when looking into the issue of harmonization building processes [8]

- De Neufville - since 2000 has been affirming that flexibility plays a key role in planning and design, as well as making it possible to adapt the reaction to the changing conditions of operation $[2,3]$

- Thomas, in the years 1999-2005, along with his research team, carried out studies on the analyses of building processes using flexibility [5,13]

- Pasławski in 2009 presented the concept of the method of flexible management through realizing building processes using the FLEMANCO method [9]

- Zavadskas and Vaidogas, in 2009, prepared and presented a work on the application of multicriterial choice when designing infrastructure [15]

- Shahu et.al., in 2012, indicated the necessity of taking flexibility into account when planning building processes along with other criteria such as: cost, deadlines and quality [12].

The traditional approach to planning and design in construction is based on the gradual elimination of the number of project-realization variants, which is illustrated by Fig. 1. It is based on one key value (e.g. traffic intensity) and thus, does not account for the possibility of changing it over time. When drawing up plans in such a way, the engineer often relies on a single average value, which provides limited information regarding the realistic values. Ultimately, the engineer, acting in accordance with the specification, regulations and building codes, as well as often financial limitations imposed by the investor, creates a project with minimal possibilities of creating different variants. Applying a range of values which may occur would be more beneficial.

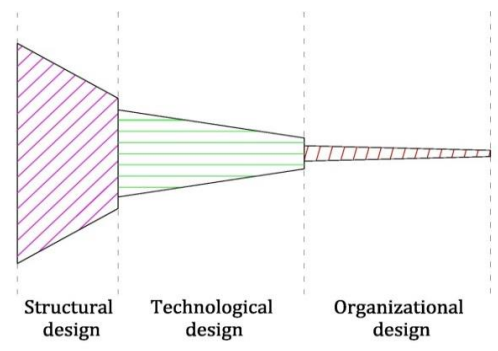

Fig. 1. Cone of construction, technological and organizational design [10] 
Meanwhile, the situation in which objects cease to serve their initial functions after a short exploitation period, or due to overly optimistic assumptions cannot be adapted to fulfill the current requirements placed upon them, ought to be counteracted. This can be done by introducing flexibility, understood as accepting the possibility of changes in the object (or system) over the course of its life cycle. Flexibility thus constitutes a method of acting in conditions of uncertainty and risk. Determining the predicted conditions of the environment for which the object or system is designed for is of a key importance here. Presented below are the basic differences between the common and proposed flexible approaches to the design.

The first significant difference is digression from the typical negative approach to risk. Thanks to flexibility, it becomes possible to reduce the probability of the occurrence of negative occurrences (losses), as well as increasing the probability of positive ones (chances).

Another significant difference is the assumption of the proactive attitude, which is based on preparing oneself for the changes that may take place and not awaiting them (and acting based on a confirmed situation). This takes on particular importance in the case of the long life cycle of objects in the transportation infrastructure, as well as the inevitability of changes in these types of systems, which stems from internal and external uncertainty.

The third element is connected with the aforementioned and concerns accounting for the possibility of introducing changes (accepting the option of expansion ought to be accepted as typical, although - as indicated by some experiences (e.g. no traffic zone in the center of cities) - the option of restricting parameters in the life cycle should also be considered.

The fourth element of this comparison is expanding the decision analysis beyond the typical technical criteria. It is a fact that in economics, the flexible approach to design is often warranted. While advances in construction technology and materials are factors which, , aid and enable the realization of many types of transformations, the deciding factor seems to be the final cost The cost of applying the flexible approach in engineering can in fact increase the cost of executing project documentation, and also lead to higher costs of project completion later on. However, when accounting for the anticipated long-term scale of the object's exploitation, applying the flexible approach may significantly influence the reduction of costs connected with the realization of specific changes in the object, which stem from the dynamics of changes in the environment. Because of this, applying the flexible approach leads to a significant reduction of the aggregated costs of the project over its entire life cycle owing to the possibility of adapting to changes which take place at the exploitation phase (flexibility options). 


\section{FLEXIBILITY IN STADIUM DESIGN}

Flexibility in Stadium design would give rise to great opportunities for the building typology.

Both in Poland and in the world big sport events are stimulating the development of city infrastructure, building new sports facilities, communications routes and increase the employment rate. They revive the regional economy. However they are connected with expenses of several million of Euro. Therefore, it is increasingly important for the money to be spent on construction of objects which will be exploited for a longer period of time without maintenance related financial losses. Since building costs are only $20 \%$ of total costs of the object, the remaining $80 \%$ are costs associated with the use, the renovation and maintaining of the building [6].

There are quite a lot of fantastic examples of the flexible design of big sports facilities in the world. An athletics stadium in Atlanta built for the Olympic Games in 1996 is one of them. It was designed for 85,000 seats and later it was partly destroyed to create the stadium for the local baseball team the Atlanta Braves with the capacity of 50,000 seats. Most of the facilities and equipment were temporary and portable - Fig 2.

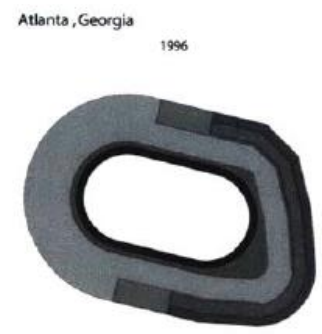

85,000 spectators

1996 Olympic Games

Construction cost: 167 million

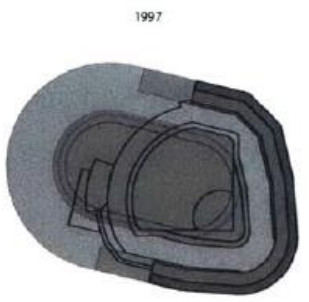

Reconfiguration from athletic to baseball stadium

Reconfiguration costs: 40 million

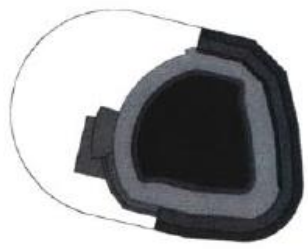

50,000 spectators

Braves baseball stadium

Reconfiguration costs: 40 million

A

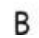

Fig. 2. Transformation of the stadium in Atlanta [6]

Another case is the Sapporo Dome in Japan (Fig.3) built for the World Cup 2002. This object has movable structural parts which were designed in order to transform the football field into a baseball field, and vice versa. The sequence of the transformations goes as follows: the artificial turf of the baseball field is first rolled up. Then the moving wallsopens towards right and left. At the same time, the outfield seats are retracted. When the hovering soccer stage starts to move, the revolving banks 
of seats also begin to move in parallel with the soccer stage; after the stage has arrived in the closed arena, it rotates 90 degrees along with the revolving banks of the seats [6].

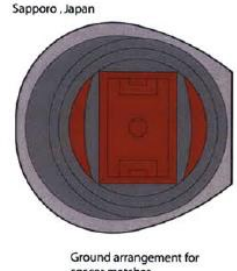

Ground arrangenct
soccer matches

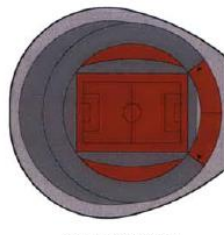

The ground is rotated

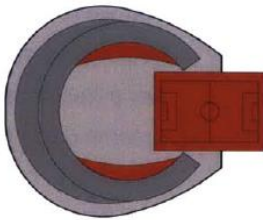

The ground is moved

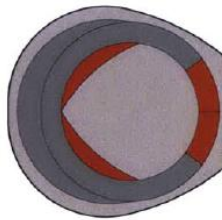

The ground is moved and converted to baseball game arrangement

Fig. 3. Transformation of the stadium in Japan [6]

But the most important flexible investment in recent years is the Olympic Town in London built for the Olympics in 2012. Each of newly built sports facilities in Stratford City is designed so that upon completion of the event it can be used by the residents.

Olympic Stadium has a demountable concept and allows the stadium to be reduced after the Games from 80.000 to 25,000 capacity. The top two tiers of the steel and concrete structure will be dismantled leaving the lowest tier with the grandstand, retaining the state of the media, changing rooms, conference and banqueting facilities. The roof will simply be lowered to fit over the reduced structure [6]. The Aquatic Centre has capacity of 20000 that will be reduced to 3500 . The water pool will be lifted out and the temporary grandstands will be disassembled. The more interesting fact is that two from Multi-Sport Arenas after the completion of the Olympics will be entirely disassembled and rebuilt in a different location in the United Kingdom. The Olympic park in London was designed in a flexible way in order to better serve people in the future.

\section{CASE STUdY - NATional StadiUm in WARSAW}

Four stadiums were built: in Warsaw, Poznań, Gdańsk and Wrocław for the UEFA European Championships in 2012 in Poland. None of them has a flexible designed structure, none will be disassembled or reduced after the championships. However the National Stadium can be referred to as a flexible sports facility do to its many available solutions. It was equipped with the folding roof adjusted to be used throughout the year, a football pitch which was also adapted to play the American football by widening and moving podiums away from the main field, the same treatment used for 
putting the athletics running track around the court. Additionally there is the biggest conference center in Warsaw located on stadium premises. Such treatments allowed to create a multifunctional sports facility, enabling the organization of sport shows, musical concerts or cultural events.

\subsection{COSTS AND PROFITS}

As every commercial civil building, the National Stadium generates costs connected with the service of the object such as: labor costs, costs of utilities, the change of turf, maintenance or security, which in the first year of use (2013) amounted to about $35.1 \mathrm{~m}$ PLN. Their percentage breakdown is presented in Fig.5 Since the stadium was flexibly designed and is a multifunctional sports facility it brought profits amounting to $18.5 \mathrm{~m}$ PLN to the state in 2013, which percentage breakdown is introduced in Fig 4.

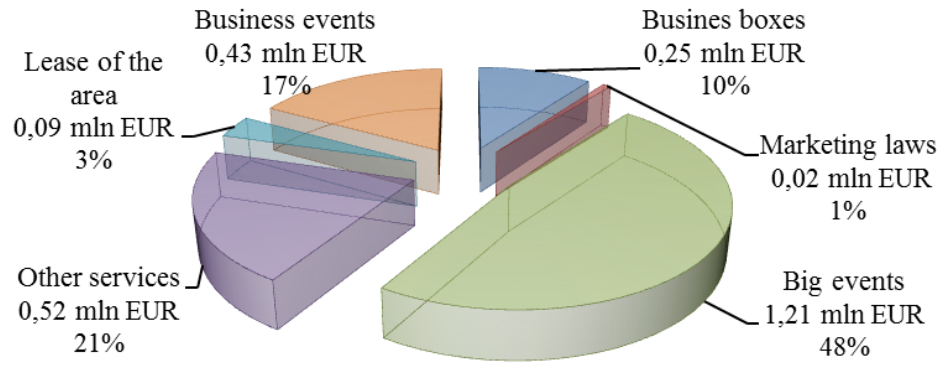

Fig. 4. Profits from the commercial activity of the National Stadium [16]

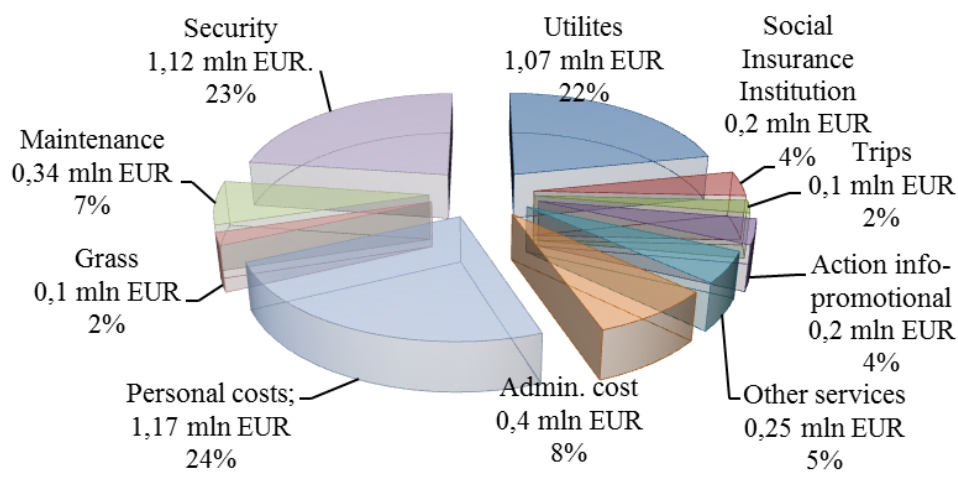

Fig. 5. Cost structure of functioning of the National Stadium [16] 


\subsection{CASE STUdy}

The main aim of conducting the social - economic analysis is to prove, that the applied investment variant at the construction of the National Stadium is justified from a social stand point. The analysis regarding the comparison of the construction and exploitation of the National Stadium with the Stadium of the same capacity, designed with the use of traditional design solutions (building costs were calculated as the average building cost of one place on podiums). The fundamental computational assumptions are:

Working and maintenance costs were based on annual financial results

The amount of profits was determined for the forecasted individual years, applying appropriate growth indicators

Both variants were analyzed for the same period of time

The same discount rates - $12 \%$ were accepted for both variants, as well as the lack of providing credit for investment, a rise in the income of 3\% per annum and a cost increase at the level of 5\%

\subsubsection{RESULTS AND CONCLUSIONS}

ENPV (economic net present value) values for both options obtained as a result of the analysis is presented in Fig. 6. The comparison of the economic net present value for both projects indicates a clear advantage of the flexibility.

Calculations show that although the cost of the National Stadium in Warsaw is much higher than the cost of the Stadium "X" (identical area) designed in the traditional way, the graph for the elastic stadium is more convex than the flat graph of the stadium designed in a traditional way - Fig.6. It means that flexible investment is more profitable, since in the future it can bring returns on the initial expenditure more quickly.

The obtained results confirm the idea of introducing flexibility which involves limiting the possibility of losses and increasing the possibility of taking advantage of opportunities.

The discussed case consideredenlarging the field of the pitch so that it is possible to practice sports of different type, creating the possibility of holding a conference or business meetings at the stadium and installing the mobile roof, enabling the organizers to hold parties and meetings in any season. It is due to such possibilities that sports facilities such as the National Stadium in Warsaw, designed with the help of flexible tools, can be used by citizens for years. 


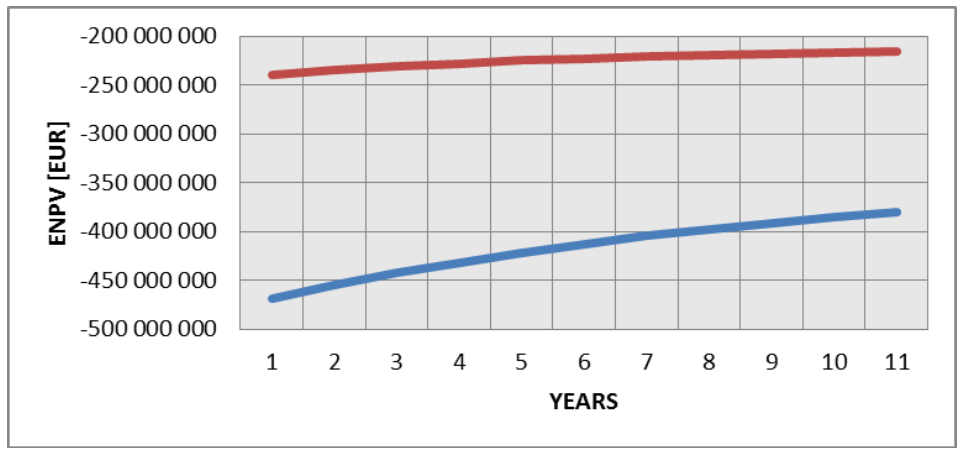

Fig. 5. ENPV disintegration for the case study

\section{Conclusions}

The example presented in the article along with the described theoretical basis behind the flexible approach to project design allows us to draw the following conclusions:

- A key issue when introducing flexibility to project design is the readiness for changes at any given stage of realizing the project (as opposed to the reactive approach applied in traditional project design).

- A major drawback of the traditional approach to project design is using average values established in a deterministic way as the basis. This can lead to restricting the possibilities of adapting to the changing environment in which the object is functioning (increasing costs during modernization and adaptation when compare to the variant involving flexibility).

- The following are important elements in applying flexibility:

- the analyzed phase of the life cycle (introducing flexibility to project design is especially beneficial due to the high potential of illegalities)

- the scope of the effect of uncertainty (range of changes and amount of affecting factors)

- ENPV (economic net present value) according to the analysis presented in the article is an effective method of assessing the effects of applying flexibility.

- The flexible approach to project design gives investors more advantageous perspectives, not guaranteed by traditional design. This tool stresses the value of flexibility. 


\section{REFERENCES}

1. C. A. Arboleda, D. M. Abraham, "Evaluation of flexibility in capital investments of infrastructure systems", in Engineering Construction and Architectural Management, 13(3) 254-274, 2006

2. R. De Neufville, "Dynamic strategic planning for technology policy", in International Journal of Technology Management, 19, 225-245, 2000

3. R. De Neufville, "Uncertainty management for engineering systems planning and design", Faculty Monograph, MIT Engineering Systems Symposium, Cambridge, MA, 2004

4. K. Das, "Integrating effective flexibility measures into a strategic supply chain planning model", in European Journal of Operational Research, 211(1), 170-183, 2011

5. M. J. Horman, H. R. Thomas, "Role of inventory buffers in construction labor performance", in fJournal of Construction Engineering and Management, 131, 834-843, 2005

6. G. Jakimowska, "Exploring Flexibility in Stadium Design”, Technische Universitst Berlin, 2007

7. O. A. Joseph, R. Sridharan, „Effects of flexibility and scheduling decisions on the performance of an FMS: Simulation modelling and analysis", in International Journal of Production Research, 50(7) 2058-2078, 2012

8. O. Kapliński, „Harmonizacja cyklicznych procesów budowlanych w ujęciu stochastycznym”, Wydawnictwo Politechniki Poznańskiej, Nr. 91, 1978

9. J. Pasławski, „Elastyczność w zarządzaniu realizacją procesów budowlanych”, Wydawnictwo Politechniki Poznańskiej, Nr.437, 2009

10. J. Pasławski, M. Różdżyńska, "Flexible Approach in Infrastructure Design Buffer Parking Case Study", in Procedia Engineering, No. 57/201, 882-888, 2013

11. J. Schumpeter, "The theory of economic development", Harvard University Press, Cambridge, MA, 1934

12. R. Shahu, A. K. Pindur, "Ganapathy . An Empirical Study on Flexibility: A Critical Success Factor of Construction Projects”, in Global Journal of Flexible Systems Management, 13(3):123-128, 2012

13. R. Thomas, M. J. Horman, "Fundamental principles of workforce management", in Journal of Construction Engineering \& Management, 132, 97-104, 2006

14. H. Volberda,, "Building the flexible firm. How to remain competitive", Oxford University Press, 1998

15. E. K. Zavadskas, E. R. Vaidogas, "Multictribute selection from alternative designs of infrastructure components for accidental situations", in Computer-Aided Civil and Infrastructure Engineering, 24(5) 346-358, 2009

16. "Wyniki działalności Stadionu Narodowego za okres 01-07.2013”, www.stadionnarodowy.org.pl

\section{LIST OF FIGURES AND TABLES:}

Fig. 1. Cone of construction, technological and organizational

Rys. 1. Stożek projektowania konstrukcyjnego technologiczno-organizacyjnego

Fig. 2. Transformation of the stadium in Atlanta

Rys. 2. Transformacja stadionu w Atlancie

Fig. 3. Transformation of the stadium in Japan

Rys. 3. Transformacja stadionu w Japonii

Fig. 4. Profits from the commercial activity of the National Stadium

Rys. 4.Przychody z działalności komercyjnej Stadionu Narodowego

Fig. 5. Cost structure of functioning of the National Stadium

Rys. 5. Struktura kosztów funkcjonowania Stadionu Narodowego

Fig. 6. ENPV disintegration for the case study

Rys. 6 Rozkład ENPV dla analizowanego przypadku 


\section{ELASTYCZNE PROJEKTOWANIE WIELKOGABARYTOWYCH OBIEKTÓW SPORTOWYCH}

Keywords: elastyczność, obiekty sportowe, projektowanie, wartość bieżąca netto

\section{SUMMARY:}

Podjęta w artykule tematyka ma na celu ukazanie zagadnienia, jakim jest elastyczne projektowanie w budownictwie. Podczas projektowania obiektów budowlanych należy uwzględnić współdziałanie ze sobą różnych systemów oraz gotowość do zmian w cyklu życia obiektu.

Szybki postęp technologiczny i turbulentnie zmienne otoczenie są czynnikami, które generują znaczne trudności w projektowaniu obiektów budowlanych, a zwłaszcza obiektów przestrzeni publicznej, w tym wielkogabarytowych obiektów sportowych. Istotnym zagadnieniem jest możliwość przygotowania projektu przedsięwzięcia z uwzględnieniem gotowości do zmian w cyklu jego życia. To właśnie elastyczność w projektowaniu daje szansę dostosowania do możliwych zmian.

Tradycyjne projektowanie posiada wady, gdyż najczęściej bazuje na jednej deterministycznie określonej wartości, natomiast elastyczne podejście do projektowania pozwala dostosować obiekty do zmieniających się realiów funkcjonowania w ciągu cyklu życia obiektu.

Pierwszy rozdział artykułu został poświęcony wyjaśnieniu definicji elastyczności, który ostatecznie proponuje następujące definicje elastyczności, w zależności od etapów procesu inwestycyjnego:

Fazy realizacji: zdolność systemu do działania w sposób umożliwiający przełączanie w sposób odwracalny różnych taktyk odpowiednio do zmieniającego się otoczenia bazujący na podejściu proaktywnym (monitoring procesów w toku $\mathrm{i}$ otoczenia) mający na celu ograniczenie zagrożeń i wykorzystanie szans, zakładający maksymalizację wartości zysku (przy stałej cenie umownej oznacza to minimalizację kosztów)

Fazy eksploatacji: zdolność systemu do przełączania różnych opcji elastyczności w zależności od zmieniających się warunków zewnętrznych w trakcie eksploatacji zakładający maksymalizację wartości NPV (Net Present Value).

Kolejny rozdział został poświęcony rozpoznaniem literaturowym pomiędzy tradycyjnym podejściem a elastycznym projektowaniem oraz omówiono cztery podstawowe różnice między nimi, takie jak: postawa proaktywna, podejście do ryzyka, możliwość wprowadzenia zmian czy analiza projektu.

Ponadto w publikacji opisano trzy obiekty sportowe, które zostały zbudowane i zaprojektowane przy pomocy narzędzi elastycznych: stadion baseballowy drużyny Bravers Atlanta w Stanach Zjednoczonych, Stadion Sapporo Dome w Japonii oraz Stadion Olimpijski w Londynie. Zaprezentowano schematy transformacji dwóch pierwszych z nich. Zagadnienie elastyczności zostało zbadane i omówione na podstawie porównania dwóch stadionów, stadionu Narodowego w Warszawie oraz fikcyjnego stadionu o takich samych gabarytach, jednakże zaprojektowanego przy pomocy tradycyjnych narzędzi projektowych. Oba przykłady zbadano przy pomocy analizy efektywności ekonomicznej metodą hybrydową, stosując jednocześnie metodę wartości bieżącej netto NPV oraz symulację. Koszty użytkowania oraz przychody zostały określone według rzeczywistych, rocznych wyników finansowych Stadionu Narodowego Zaprezentowany w artykule przykład wraz z omówioną podstawą teoretyczną zagadnienia elastycznego projektowania pozwala na sformułowanie następujących wniosków:

Kluczowym zagadnieniem podczas wprowadzenia elastyczności w projektowaniu jest gotowość do zmian na każdym etapie realizacji projektu, w przeciwieństwie do reaktywnego podejścia stosowanego w tradycyjnym projektowaniu. 
Podstawową wadą tradycyjnego podejścia w projektowaniu jest bazowanie na średniej wartości określonej w sposób deterministyczny. Może prowadzić to do ograniczenia możliwości dostosowania się do zmiennego otoczenia działania obiektu (zwiększone koszty podczas modernizacji i adaptacji niż przy zastosowaniu elastyczności)

Przedstawiona w artykule analiza ENPV stanowi skuteczną metodę szacowania efektów zastosowania elastyczności w opisywanym przypadku

Poprzez powiększenie płyty boiska tak, by można na niej uprawiać różnego typu sporty, stworzenie na stadionie możliwości odbycia konferencji czy spotkań biznesowych oraz zamontowanie mobilnego dachu, umożliwiającego odbywanie się imprez i spotkań o każdej porze roku elastyczne podejście do projektowania daje większe perspektywy inwestorom, których tradycyjne projektowanie nie posiada. Narzędzie te podkreśla wartość elastyczności.

Natomiast istotne elementy zastosowania elastyczności to:

- analizowana faza cyklu życia (szczególnie korzystne ze względu na wysoki potencjał nieprawności jest wprowadzenie elastyczności w projektowaniu)

- rozmiar odziaływania niepewności (zakres zmian oraz ilość czynników odziaływujących) 